
www.globaljournalseries.com, Email: info@globaljournalseries.com

\title{
NUTRITIONAL KNOWLEDGE AND PRACTICE OF PRE-SCHOOL FEEDING: A COMPARATIVE STUDY AMONG MOTHERS IN SLUM AND URBAN AREAS OF CALABAR, NIGERIA
}

\author{
AGAM E. AYUK, ANNE C. EDET, PHILIA A. AYUK, AND OGBAN OMORONYIA
}

(Received 20 November 2019; Revision Accepted 9 January 2020)

\begin{abstract}
In many developing countries, malnutrition has remained one of the leading causes of childhood morbidity and mortality. This is particularly important for vulnerable groups, including preschool toddlers who require adequate nutrition for physical and mental stability to face the new challenge of initiation into academic life. This study was aimed at assessing and comparing knowledge and practice of preschool feeding among mothers in urban and slum areas in Calabar, Nigeria using cross-sectional study design with researcher-administered structured questionnaire. One hundred and twenty (120) subjects were surveyed, with mean maternal age of $26.5 \pm 3.4$ years. Subjects in slum compared with urban areas had lower levels of education (primary level: $33.3 \%$ vs. $15.0 \%)(p<0.05)$. Thirty two $(32)$ subjects $(27.1 \%)$ had inadequate nutritional knowledge of preschool feeding. Poor knowledge of body building foods was significantly commoner among slum compared with urban subjects $(43.1 \%$ vs. $18.3 \%, p=0.00)$. Also, poor knowledge of adequacy of diet was significantly commoner among slum compared with urban subjects $(68.9 \%$ vs. $50.0 \%, p=0.04)$. Bread and tea (51, 42.5\%), Eba and soup (37,30.8\%) and rice (27, $22.5 \%$ ), were the most commonly consumed breakfast, lunch and dinner, respectively. Nutritional health education and further research including the use of qualitative methods for better understanding of the reasons for dietary pattern is recommended.

\section{INTRODUCTION}

Malnutrition especially undernutrition is still a severe public health problem in sub-Saharan Africa (Stephenson et al., 2000). According to United Nations Children's Fund (UNICEF), World Health Organization (WHO) and World Bank report of 2015, out of 667 million children under age 5 worldwide, 159 million are stunted, 50 million are wasted and 41 million are overweight with a greater percentage in Asia and Africa (Global nutrition report, 2016). Millions of children under 5 years of age in low and middle-income countries are failing to reach their potential in cognitive, language, and social emotional development, which has implications for their educational attainment and adult functioning (Gratham-Mcgregor et al., 2014). Poor nutrition during childhood is one important factor impeding the physical and mental development of children, which ultimately propagates the vicious cycle of intergenerational malnutrition (Olatidoye et al., 2011). The issue of child malnutrition is critical because its effects are not limited to the boundary of childhood but rather persist into adulthood. It silently destroys the future productivity of nations (Jesmin et al., 2011).

In developing countries, it is estimated that $29 \%$ of children aged less than five years (under-five children) are stunted [<-2 standard deviation (SD) height-for-age] or chronically undernourished (Jesmin et al., 2011). According to the 2008 report on the National nutrition and health survey (NNHS) of Nigeria, the global acute malnutrition (GAM) prevalence among children 659 months of age was 7.0percent, prevalence of underweight among children age $0-59$ months was $19.9 \%$. The prevalence of stunting was $32.0 \%$ and overweight prevalence was 1.2 percent. Overall only $64 \%$ of children in Nigeria are growing healthily without being stunted or wasted (NNHS, 2018). On infant and young child feeding practices nearly $60.0 \%$ of the children assessed were not fed to the recommended minimum meal frequency for their age and $65.0 \%$ do not meet the minimum dietary diversity (NNHS, 2018).

Childhood and adolescence are the formative stage of poor eating habits and this increases the risk of future chronic diseases (Ozdogan et al., 2012). The mother is the primary care giver especially during the preschool (first 6years) of life. Maternal nutritional knowledge and level of education have been shown to be critical factors determining a child's growth and development (Ozdogan
\end{abstract}

Agam E. Ayuk, Department of Family Medicine, University of Calabar, Calabar, Nigeria.

Anne C. Edet, Department of Internal Medicine, Dietetics Unit, University of Uyo Teaching Hospital, Uyo, Nigeria.

Philia A. Ayuk, Department of Statistics, University of Calabar, Calabar, Nigeria.

Ogban Omoronyia, Department of Community Medicine, University of Calabar, Calabar, Nigeria. 
et al., 2012; Abate et al., 1999; Ajao et al., 2010). Studies have reported that mother's nutritional knowledge has positive effects on child nutrition (Ozdogan et al., 2012; Variyam et al., 1999; Appoh et al., 2005; Sule et al., 2009; Verecken et al., 2010). It has been argued that maternal knowledge on pre-school feeding differs, thus childhood malnutrition persists. Also, maternal knowledge and practice of pre-school feeding in slum and urban areas is said to have been influenced by maternal work, maternal time, income, education and occupational status (Olatidoye et al., 2011).

The source of maternal nutritional education can influence feeding practices in addition to maternal education and income. This study therefore set out to assess the knowledge of preschool feeding practices of mothers in slum and urban areas in Calabar, Niger-Delta region of Cross River State.

\section{MATERIAL AND METHODS}

This cross-sectional study was carried out among randomly selected mothers of pre-school toddlers in both slum and urban areas of Calabar Municipality. Calabar is the capital of Cross River State, one of the 36 states in Nigeria. Nutritional knowledge and pattern of preschool feeding was assessed using researcheradministered structured pretested questionnaire and compared between study groups using inferential statistics. Data analysis was done using SPSS version 16 , with $p$-value set at $<0.05$. Ethical approval was obtained from the Research and Ethics unit of Cross River State Ministry of Health. Written consent was obtained from the mothers.

\section{RESULT}

One hundred and twenty (120) subjects were surveyed, with mean maternal age of $26.5 \pm 3.4$ years. Subjects in slum compared with urban areas, were younger (mean age: 24.8 vs. 28.3 years), and had lower levels of education (primary level: $33.3 \%$ vs. $15.0 \%)(p<0.05)$. Thirty two (32) subjects $(27.1 \%)$ had inadequate nutritional knowledge of preschool feeding, with no significant difference in proportion comparing slum and urban subjects $(34.5 \%$ vs. $20.0 \%, p=0.08)$. However, poor knowledge of body building foods was significantly commoner among slum compared with urban subjects $(43.1 \%$ vs. $18.3 \%, p=0.00)$. Also, poor knowledge of adequacy of diet was significantly commoner among slum compared with urban subjects $(68.9 \%$ vs. $50.0 \%$, $\mathrm{p}=0.04)$. Bread and tea $(51,42.5 \%)$, Eba and soup (37, $30.8 \%)$ and rice $(27,22.5 \%)$, were the most commonly consumed breakfast, lunch and dinner, respectively. There was no significant difference in diet pattern comparing slum and urban subjects $(p>0.05)$.

\begin{tabular}{|l|l|l|l|l|}
\hline \multicolumn{5}{|l|}{ Table 1: Sociodemographic characteristics of respondents (N=120) } \\
\hline Variable & $\begin{array}{l}\text { Slum } \\
\mathbf{n}(\%)\end{array}$ & $\begin{array}{l}\text { Urban } \\
\mathbf{n}(\%)\end{array}$ & $\begin{array}{l}\text { Total } \\
\mathbf{n}(\%)\end{array}$ & $\begin{array}{l}\text { Chi-square } \\
(\mathbf{p} \text {-value) }\end{array}$ \\
\hline Maternal age group & & & & \\
\hline$\leq 35$ years & $55(91.7)$ & $47(78.3)$ & $102(100)$ & $4.2(0.04)$ \\
\hline$>35$ years & $5(8.3)$ & $13(21.7)$ & $18(15.0)$ & \\
\hline Total & $60(100)$ & $60(100)$ & $120(100)$ & \\
\hline Marital status & & & & \\
\hline Single & $16(26.7)$ & $7(11.7)$ & $23(19.2)$ & Fishers \\
\hline Married & $43(71.7)$ & $50(83.3)$ & $93(77.5)$ & Exact \\
\hline Widowed & $1(1.7)$ & $3(5.0)$ & $4(3.3)$ & $(0.08)$ \\
\hline Total & $60(100)$ & $60(100)$ & $120(100)$ & \\
\hline Educational level & & & & \\
\hline None & $3(5.0)$ & $4(6.6)$ & $7(5.8)$ & Fishers \\
\hline Primary & $20(33.3)$ & $9(15.0)$ & $29(24.2)$ & Exact \\
\hline Secondary & $26(43.3)$ & $21(35.0)$ & $47(39.2)$ & $(0.01)$ \\
\hline Tertiary & $11(18.3)$ & $26(43.3)$ & $37(30.8)$ & \\
\hline Total & $60(100)$ & $60(100)$ & $120(100)$ & \\
\hline Occupation & & & & \\
\hline Business / trader & $21(37.5)$ & $20(41.7)$ & $41(39.4)$ & Fishers \\
\hline Artisan & $11(19.6)$ & $7(14.6)$ & $18(17.3)$ & Exact \\
\hline Housewife / unemployed & $10(17.9)$ & $4(8.3)$ & $14(13.5)$ & $(0.57)$ \\
\hline Civil/public servant & $8(14.3)$ & $9(18.8)$ & $17(16.3)$ & \\
\hline Clergy & $3(5.4)$ & $4(8.3)$ & $7(6.7)$ & \\
\hline Student & $2(3.6)$ & $4(8.3)$ & $6(5.8)$ & \\
\hline Farmer & $1(1.8)$ & $0(0.0)$ & $1(1.8)$ & \\
\hline Total & $56(100)$ & $48(100)$ & $104(100)$ & \\
\hline Number of children & & & & \\
\hline$\leq 4$ & $50(83.3)$ & $56(93.3)$ & $106(88.3)$ & Fishers \\
\hline$>4$ & $10(16.7)$ & $4(6.6)$ & $14(11.7)$ & Exact \\
\hline Total & $60(100)$ & $60(100)$ & $120(100)$ & $(0.09)$ \\
\hline & & & & \\
\hline & & & & \\
\hline
\end{tabular}




\begin{tabular}{|c|c|c|c|c|}
\hline Variable & $\begin{array}{l}\text { Slum } \\
\mathrm{n}(\%)\end{array}$ & $\begin{array}{l}\text { Urban } \\
\mathrm{n}(\%)\end{array}$ & $\begin{array}{l}\text { Total } \\
\text { n (\%) }\end{array}$ & $\begin{array}{l}\text { Chi-square } \\
\text { (p-value) }\end{array}$ \\
\hline \multicolumn{5}{|l|}{$\begin{array}{l}\text { Prior exposure to } \\
\text { nutritional counseling }\end{array}$} \\
\hline Yes & $37(62.7)$ & $47(78.3)$ & $84(70.6)$ & $3.5(0.06)$ \\
\hline No & $22(37.3)$ & $13(21.7)$ & $35(29.4)$ & \\
\hline Total & 59 9100) & $60(100)$ & $119(100)$ & \\
\hline \multicolumn{5}{|l|}{ Source of information } \\
\hline Health facility & $18(48.6)$ & 34 (73.9) & $52(62.7)$ & Fishers \\
\hline Media & $8(21.6)$ & $9(19.6)$ & $17(20.5)$ & Exact \\
\hline Friend/relative & $10(27.0)$ & $3(6.5)$ & $13(15.6)$ & $(0.02)$ \\
\hline Total & $37(100)$ & $46(100)$ & $83(100)$ & \\
\hline \multicolumn{5}{|l|}{$\begin{array}{l}\text { Correct knowledge of } \\
\text { body building foods }\end{array}$} \\
\hline Yes & $33(56.9)$ & $49(81.7)$ & $82(69.5)$ & $8.5(0.00)$ \\
\hline No & $25(43.1)$ & $11(18.3)$ & $36(30.5)$ & \\
\hline Total & $58(100)$ & $60(100)$ & $118(100)$ & \\
\hline \multicolumn{5}{|l|}{$\begin{array}{l}\text { Correct knowledge of } \\
\text { adequate diet }\end{array}$} \\
\hline Yes & $18(31.0)$ & $30(60.0)$ & $48(40.7)$ & $4.4(0.04)$ \\
\hline No & $40(68.9)$ & $30(50.0)$ & $70(59.3)$ & \\
\hline Total & $58(100)$ & $60(100)$ & $118(100)$ & \\
\hline \multicolumn{5}{|l|}{$\begin{array}{l}\text { Correct knowledge of } \\
\text { proper feeding pattern }\end{array}$} \\
\hline Yes & $20(33.9)$ & $18(30.5)$ & $38(32.2)$ & $0.16(0.69)$ \\
\hline No & $39(66.1)$ & $41(69.5)$ & $80(67.8)$ & \\
\hline Total & $59(100)$ & $59(100)$ & $118(100)$ & \\
\hline \multicolumn{5}{|l|}{ Knowledge score grade } \\
\hline Excellent $(\geq 70 \%)$ & $27(46.5)$ & $36(60.0)$ & $63(53.4)$ & Fishers \\
\hline Good (50-69\%) & $11(19.0)$ & $12(20.0)$ & $23(19.5)$ & Exact \\
\hline Fair (40-49\%) & $8(13.8)$ & $4(6.7)$ & $12(10.2)$ & $(0.33)$ \\
\hline Poor (0-39\%) & $12(20.7)$ & $8(13.3)$ & $20(16.9)$ & \\
\hline Total & $58(100)$ & $60(100)$ & $118(100)$ & \\
\hline \multicolumn{5}{|l|}{$\begin{array}{l}\text { Knowledge grade } \\
\text { category }\end{array}$} \\
\hline Adequate knowledge & 38 (65.5) & $48(80.0)$ & $86(72.9)$ & $3.1(0.08)$ \\
\hline Inadequate knowledge & $20(34.5)$ & $12(20.0)$ & $32(27.1)$ & \\
\hline Total & $58(100)$ & $60(100)$ & $118(100)$ & \\
\hline & & & & \\
\hline
\end{tabular}

\begin{tabular}{|l|l|l|l|l|}
\hline \multicolumn{6}{|l|}{ Table 3: 24-hr breakfast recall among respondents (N=120) } \\
\hline Variable & $\begin{array}{l}\text { Slum } \\
(\mathbf{\%})\end{array}$ & $\begin{array}{l}\text { Urban } \\
(\%)\end{array}$ & $\begin{array}{l}\text { Total } \\
\mathbf{n}(\%)\end{array}$ & $\begin{array}{l}\mathbf{p}- \\
\text { value }\end{array}$ \\
\hline Bread \& Tea & $26(43.3)$ & $25(41.7)$ & $51(42.5)$ & Fishers \\
\hline Beans & $7(11.7)$ & $6(10.0)$ & $13(10.8)$ & Exact \\
\hline Rice & $4(6.7)$ & $6(10.0)$ & $10(8.3)$ & $(0.99)$ \\
\hline Yam & $4(6.7)$ & $3(5.0)$ & $7(5.8)$ & \\
\hline Eba \& Soup & $3(5.0)$ & $2(3.3)$ & $5(4.2)$ & \\
\hline Plantain & $6(10.0)$ & $6(10.0)$ & $12(10.0)$ & \\
\hline Rice \& Beans & $5(8.3)$ & $6(10.0)$ & $11(9.2)$ & \\
\hline Yam \& Beans & $5(8.3)$ & $6(10.0)$ & $11(9.2)$ & \\
\hline Total & $60(100)$ & $60(100)$ & $120(100)$ & \\
\hline
\end{tabular}




\begin{tabular}{|l|l|l|l|l|}
\hline Table 4: 24-hr lunch recall among respondents $(\mathrm{N}=120)$ \\
\hline Variable & $\begin{array}{l}\text { Slum } \\
(\mathbf{\%})\end{array}$ & $\begin{array}{l}\text { Urban } \\
(\mathbf{\%})\end{array}$ & $\begin{array}{l}\text { Total } \\
(\mathbf{\%})\end{array}$ & $\begin{array}{l}\mathbf{p}- \\
\text { value }\end{array}$ \\
\hline Bread \& Tea & $0(0.0)$ & $0(0.0)$ & $0(0.0)$ & Fishers \\
\hline Beans & $10(16.7)$ & $8(13.3)$ & $18(15.0)$ & Exact \\
\hline Rice & $0(0.0)$ & $6(10.0)$ & $6(5.0)$ & $(0.36)$ \\
\hline Yam & $16(26.7)$ & $14(23.3)$ & $30(25.0)$ & \\
\hline Eba \& Soup & $17(28.3)$ & $20(33.3)$ & $37(30.8)$ & \\
\hline Plantain & $6(10.0)$ & $5(8.3)$ & $11(9.2)$ & \\
\hline Rice \& Beans & $7(11.7)$ & $4(6.7)$ & $11(9.2)$ & \\
\hline Yam \& Beans & $4(6.7)$ & $3(5.0)$ & $7(5.8)$ & \\
\hline Total & $60(100)$ & $60(100)$ & $120(100)$ & \\
\hline
\end{tabular}

\begin{tabular}{|l|l|l|l|l|}
\hline \multicolumn{6}{|l|}{ Table 5: 24-hr dinner recall among respondents $(\mathrm{N}=120)$} \\
\hline Variable & $\begin{array}{l}\text { Slum } \\
\mathbf{n}(\mathbf{\%})\end{array}$ & $\begin{array}{l}\text { Urban } \\
\mathbf{( \% )}\end{array}$ & $\begin{array}{l}\text { Total } \\
\mathbf{( \% )}\end{array}$ & $\begin{array}{l}\mathbf{p}- \\
\text { value }\end{array}$ \\
\hline Bread \& Tea & $5(8.3)$ & $3(5.0)$ & $8(6.7)$ & Fishers \\
\hline Beans & $8(13.3)$ & $7(11.7)$ & $15(12.5)$ & Exact \\
\hline Rice & $9(15.0)$ & $18(30.0)$ & $27(22.5)$ & $(0.61)$ \\
\hline Yam & $8(13.3)$ & $10(16.7)$ & $18(15.0)$ & \\
\hline Eba \& Soup & $13(21.7)$ & $8(13.3)$ & $21(17.5)$ & \\
\hline Plantain & $6(10.0)$ & $5(8.3)$ & $11(9.2)$ & \\
\hline Rice \& Beans & $4(6.7)$ & $4(6.7)$ & $8(6.7)$ & \\
\hline Yam \& Beans & $7(11.7)$ & $5(8.3)$ & $12(10.0)$ & \\
\hline Total & $60(100)$ & $60(100)$ & $120(100)$ & \\
\hline
\end{tabular}

\section{DISCUSSION}

This study aimed at assessing nutritional knowledge and practice of pre-school feeding among slum and urban mothers in Calabar municipality. The level of education in the slum areas was lower than that in the urban areas with $33.3 \%$ of slum mothers having primary education compared to $15 \%$ of urban mothers. These findings were consistent with findings of Sujauddoula et al, 2018 and Ahsan et al, 2017 that mothers in slums are less likely to have higher levels of education. Also, several studies have positively correlated level of mother's education and knowledge, attitude and practice of child nutrition (Dhone et al., 2012, Ndukwu et al., 2013). A study in Ile-Ife, Nigeria noted that maternal education has been consistently shown to be critically important for child health, nutrition, and survival. It also noted that mothers in slum areas are more likely to be less educated. Although the precise mechanism by which maternal education affects child outcomes is not fully understood, evidence from various countries indicates that knowledge and practices are key pathways. Educated women are likely to be more aware of preschool feeding, nutrition, hygiene and health care (Ajao, 2010). Thirty two (32) subjects $(27.1 \%)$ had inadequate nutritional knowledge of preschool feeding, with no significant difference in proportion comparing slum and urban subjects $(34.5 \%$ vs. $20.0 \%, p=0.08)$. Sangra et al reported similar finding of $23 \%$ of mothers having inadequate nutritional knowledge (Sangra et al., 2019). This correlates with higher health numeracy and nutritional knowledge among more educated non-slum dwellers (Ndukwu et al., 2013). However, Kabir et al, in their study in slum areas of Bangladesh reported adequate nutritional knowledge among slum mothers, although this finding was reported to be due to a community based intervention (Kabir et al., 2017)

The present study found that poor knowledge of body building foods was significantly commoner among slum compared with urban subjects $(43.1 \%$ vs. $18.3 \%$, $\mathrm{p}=0.00$ ). Also, poor knowledge of adequacy of diet was significantly commoner among slum compared with urban subjects $(68.9 \%$ vs. $50.0 \%, p=0.04)$. This finding is consistent with report by Reiher et al that mothers were not knowledgeable of what a balanced diet is to be given to their child (Reiher et al., 2017). Similar study in the environment revealed low maternal nutritional knowledge (Jemide et al, 2016). Likewise, Palwala et al (2009) in their study of nutritional quality of diets of children in urban slums in India attributed nutritional inadequacy of children to inappropriate knowledge among mothers and care givers. Their intervention of intensive nutritional education revealed favorable behavioural change among mothers that improved the dietary quality and nutrient intakes of young children in urban slums.

This study revealed that there is a need to increase the nutritional knowledge of both slum and urban mothers especially mothers in the slum. This is because the more nutritional knowledge a mother has, the better the dietary intake of the children (Yabanci et al., 2014). A study on the associations between parenting styles and nutrition knowledge concluded that interventions targeting a range of positive and supportive parenting practices in conjunction with nutrition knowledge education for parents will help in pre-school feeding (Peters et al., 2012).

Targeting the source of nutritional information is very important. This study found that mothers in both slum 
and urban areas received most of their nutritional information from health facilities $(62.7 \%)$, with slum versus urban spread of $48.6 \%$ and $73.9 \%$ respectively. This was followed by the media $21.6 \%$ and $19.6 \%$ for slum and urban mothers respectively with $p=0.02$. This means that interventions of improving nutritional knowledge of mothers should be targeted at health facilities and the media in addition to other educational interventions like schools and market places.

Sometimes mothers do not know the importance of variety and balance in the diet and the right amount and types of foods needed by children to meet these dietary needs. Without adequate nutritional knowledge, malnutrition and poor nutritional status may occur in households with sufficient income, food and health services. This is not to say that mothers of malnourished children are necessarily ignorant or that all illiterate mothers whether their children are healthy or not, are ignorant, but their knowledge level on child health and nutrition can have a major toll on the children's general health (Jemide et al., 2016).

In conclusion, there is an urgent need to improve nutritional knowledge of mothers in both slum and urban areas because of the benefits to the child and family. Government and Non Governmental Organisations (NGO) interventions should among other methods of health education intensify nutritional education at health facilities where mothers visit for antenatal care and immunizations and the electronic and news media with wider reach.

\section{REFERENCES}

Abate, G., Kogi-Makau W., Muroki N.M., 1999. Childfeeding practices as predictors of nutritional status of children in a slum area in Addis Ababa, Ethiopia. Ethiop. J. Health Dev 13(3):229-2.

Ajao, K.O., Ojofeitimi, E.O., Adebayo, A. A., Fatusi, A. O., Afolabi, O. T. 2010. Influence of family size, household food security status, and child care practices on the nutritional status of under-five children in lle-lfe, Nigeria. Afr J Reprod Health. 14[4]: 123-132).

Ahsan, K. Z., Arifeen, S. E, Al-Mamun, A, Khan S. H, Chakraboty, N.2017. Effects of individual, household and community characteristics on child nutritional status in the Slums of urban Bangladesh. Archives of Public Health.75:9.

Appoh, L. Y and Krekling, S. 2005. Maternal nutritional knowledge and child nutritional status in the Volta Region of Ghana. Maternal and Child Nutrition 1(2):100-110.

Dhone, A. B, Chitnis, U. B, Bhawalkar, J. S, Jadhav, S. L.2012. Epidemiological study of under nutrition among under fi ve years children in an urban slum. Med J DY Patil Univ. 5:110-3.

Global Nutrition Report 2016. International Food Policy Research Institute. From Promise to Impact: Ending Malnutrition by 2030. Washington, DC.
Grantham-McGregor, S. M, Fernald L.C.H, Rose M. C, Kagawa R.M.C, Walker S.2014 Effects of integrated child development and nutrition interventions on child development and nutritional status. Ann. N.Y. Acad. Sci.11-32.

Hoque, M. A, Sayeed, M. A, Ahsan, M. R, Mamun, M.A.A, Salim, F. 2016, Nutritional Status among under-5 Children of a selected slum in Dhaka city. Northern International Medical College Journal, 7: 143-145.

Jemide, J. O, Ene-Obong, H. N, Edet, E.E, Udoh, E.E. 2016. Association of maternal nutrition knowledge and child feeding practices with nutritional status of children in Calabar South Local Government Area, Cross River State, Nigeria. IJHS. 2(1): 293-298.

Jesmin, A, Yamamoto, S.Y, Malik, A. A, Haque, A. M. 2011. Prevalence and determinants of chronic malnutrition among preschool children: A crosssectional study in Dhaka City, Bangladesh. J Health Popul Nutr. 29(5):494-499.

Kabir, A, Maitrot, M.R.L. 2017. Factors influencing feeding practices of extreme poor

infants and young children in families of working mothers in Dhaka slums: A qualitative study. PLoS ONE 12(2): e0172119.

National nutrition and health survey (NNHS). 2018. Report on the nutritional and health situation of Nigeria. June 2018.

Ndukwu, C.I, Egbuonu I, Ulasi, T.O, Ebenebe, J.C. 2013. Determinants of undernutrition among primary school children residing in slum areas of a Nigerian city. Niger J Clin Pract.16:178-83.

Olatidoye, O.P, Adebusoye, S.M, , Adekola, A.G, Jatto, W.O. 2011. Effect of maternal employment on nutritional status of pre-school children from low income households' area of Oyo State. EJEAFChe.10(7): 2574-2580.

Özdoğan, Y, Uçar A, Akan, L.S, Yılmaz, M. V, Sürücüoğlu, M. S, Funda Pınar Çakıroğlu, F. P and Özçelik, A. O. 2012. Nutritional knowledge of mothers with children aged between 0-24 months. Journal of Food, Agriculture and Environment. Vol.10 (1): 173-175.

Palwala, M, Sharma, S, Udipi, S.A, Ghugre, P.S, Kothari, $\mathrm{G}$ et al. 2009. Nutritional quality of diets fed to young children in urban slums can be improved by intensive nutrition education. Food and Nutrition bulletin. 30;4.

Peters, J., Dollman, J., Petkov, J., Parletta, N. 2012. Associations between parenting styles and nutrition knowledge and 2-5-year-old children's fruit, vegetable and non-core food consumption. Public Health Nutrition, 16(11): 1979-1987. 
Reiher, A, Mohammadnezhad, M. 2017. Awareness and characteristics of the mothers of malnourished children under 5 years old on south Tarawa, Kiribati in 2016: a descriptive study. MOJ Womens Health.6(1):332-336.

Sangra S, Nowreen N. 2019. Knowledge, attitude, and practice of mothers regarding nutrition of underfive children: A cross-sectional study in rural settings. Int J Med Sci Public Health. 8(5):392394.

Stephenson, L.S, Latham, M.C, Ottesen, E.A. 2000. Malnutrition and parasitic helminth infections. Parasitology. 121(Suppl):S23-38.

Sule, S. S., Onayade, A. A., Abiona, T. C., Fatusi, A. O., Ojofeitimi, E. O., Esimai, O. A. and ljadunola, K. T. 2009. Impact of nutritional education on nutritional status of under-five children in two rural communities of south-west Nigeria. Niger Postgrad. Med. J. 16(2):115- 125.
Sujauddoula, A. I, Amin, A.F.M, Debnath, S.C, Galib, A, Rouf, A, Hague, E, et al. 2018. Socio-economic status and feeding practices among the mothers of under-five children in an urban slum of Bangladish: a cross-sectional study. Asian J. Med. Biol. Res. 4(3):307-314.

Variyam, J., Blaylock, J., Lin, B., Ralston, K. and Smallwood, D. 1999. Mother's nutrition knowledge and children's dietary intakes. American Journal of Agricultural Economics 81:373-384.

Vereecken, C. and Maes, L. 2010. Young children's dietary habits and associations with the mothers' nutritional knowledge and attitudes. Appetite 54:44-51.

Yabanci, N, Kisac, I, Karakus, S. S. 2014. The effects of mother's nutritional knowledge on attitudes and behaviors of children about nutrition. ProcediaSocial and Behavioural Sciences.116;44774481. 